\title{
Rawls, Reasonableness, and International Toleration
}

\section{Thomas Porter}

Forthcoming in Politics, Philosophy \& Economics

\begin{abstract}
$\underline{\text { Abstract }}$
Rawls's account of international toleration in The Law of Peoples has been the subject of vigorous critiques by critics who believe that he unacceptably dilutes the principles of his Law of Peoples in order to accommodate non-liberal societies. One important component in these critiques takes issue specifically with Rawls's inclusion of certain non-liberal societies ('decent peoples') in the constituency of justification for the Law of Peoples.
\end{abstract}

In Rawls's defence, I argue that the explanation for the inclusion of decent peoples in the constituency of justification is not, as is standardly assumed, that they are the kind of societies that ought to be tolerated in that way on some prior conception of which kinds of societies ought to be tolerated in that way. The real explanation appeals to a methodological principle underlying Rawls's approach to political justification, according to which liberals owe justification, as a matter of liberal principle, to those who comply with liberal principles for political institutions that apply to them. If such liberal principles can be complied with by agents who nevertheless cannot accept fully liberal justifications for those principles, then liberalism itself requires liberals to seek justifications which they can accept.

This approach gives us a new way to view decent peoples: as just such agents, who are therefore owed a justification for the Law of Peoples that they can accept. Decency is thus a concept that is internal to liberal political justification at international level. Reading Rawls in this way permits a coherent and attractive defence of his strategy of toleration and of his international theory as a whole. 
$\underline{\text { Keywords }}$

Global justice, Rawls, Law of Peoples, cosmopolitanism, political liberalism

\section{Introduction}

To what extent should liberal societies be tolerant of non-liberal societies in their foreign policy? And what form should any such toleration take? Should they criticise or even invade liberalrights violating states in order to encourage the establishment of more liberal regimes there? Or are there ways to organise non-liberal societies so that they are, from a liberal point of view, worthy of toleration and even respect?

It's a familiar fact that Rawls's The Law of Peoples gives what have seemed to many liberals to be rather disappointing answers to these urgent questions. Rawls advocates toleration for 'decent peoples'—non-liberal societies that meet certain minimal conditions-whose human rights records and aims may fall far short of those of liberal societies. Such toleration extends beyond mere non-intervention in decent peoples' domestic affairs to ensuring that decent peoples can accept the principles that regulate liberal societies' interactions with them. As it happens, the principles of the 'Law of Peoples' that Rawls advocates, and works out in the first instance by appeal to a choice situation involving only representatives of liberal peoples, turn out to be principles that could also be accepted in the relevant sense by decent peoples. So, Rawls concludes, the liberal Law of Peoples also expresses an appropriate degree of toleration for decent peoples. ${ }^{1}$

Some find these conclusions reprehensibly unambitious. Critics suspect, in particular, that it is not merely a happy coincidence that decent peoples could accept the principles of the Law of Peoples. Rawls, they believe, has diluted the principles of the Law of Peoples precisely in order to accommodate decent peoples. They see this as an unprincipled concession to unreasonableness. $^{2}$ 
In fact, as I'll argue, there are two distinct objections underpinning these critics' concerns. Both they and defenders of Rawls fail to distinguish these objections adequately. The first is that the liberal peoples-involving choice situation to which Rawls appeals in the first instance to justify the Law of Peoples in fact justifies a stronger set of principles (and not those of the Law of Peoples). This stronger set of principles would justify greater criticism of or intervention in decent peoples' domestic affairs. In that sense, then, a properly liberal law of peoples should be less tolerant of decent peoples than Rawls supposes.

The second objection is that it is inconsistent of Rawls, given his liberalism at the domestic level, to seek principles that are acceptable to decent-i.e. illiberal-peoples. According to this objection, even if the correct liberal law of peoples turns out to be non-interventionist, for one reason or another, it is irrelevant to its justification whether any decent peoples accept it or not. In this second sense, then, the Rawlsian strategy of toleration is mistaken.

Prominent defenders of Rawls tend to focus on the first objection, arguing that Rawls's choice-situation argument for the Law of Peoples does in fact justify what critics see as the excessive non-interventionism of that set of principles. But even if these defenders are right, that doesn't address the second objection. It may be that Rawls's arguments do justify a noninterventionist law of peoples. But why, at least as a matter of ideal theory, should we also care whether or not decent peoples could accept it? Thus, even if the defenders of Rawls can rebut the first objection, the concern that Rawls's view is too tolerant of illiberal societies remains in the form of the second.

I'll argue that Rawls can be defended from this charge. My argument, in outline, is as follows. The explanation for Rawls's efforts to show that decent peoples could accept the Law of Peoples is not, as many suppose, that decent peoples are the kind of people who ought to be tolerated in that way, on some prior conception of which kinds of people ought to be tolerated in that way. If that explanation were correct, then suspicions that Rawls dilutes fully liberal principles in order to ensure that they will be acceptable to decent peoples would be difficult to 
dispel. The explanation is, rather, that there is a fundamental methodological principle underlying Rawls's approach to political justification—both domestically and internationally_ according to which liberals owe justification, as a matter of liberal principle, to those who comply with liberal principles of justice that apply to them. Therefore, if such liberal principles can be complied with (by which I mean internalised and acted from $)^{3}$ by agents who nevertheless cannot accept fully liberal justifications for those principles, then liberalism itself requires liberals to seek justifications for them which these non-liberal compliers can accept.

Decent peoples are, on my reading, just those non-liberal societies who nevertheless comply liberal principles for international political institutions that apply to them. So, if defenders of Rawls against the first objection are right that a fully liberal justification does not entail a greater degree of interventionism than Rawls's Law of Peoples implies, so that decent peoples thus defined are possible, then according to the methodological principle decent peoples are owed a justification for the Law of Peoples that they can accept. This is the explanation for Rawls's strategy of toleration. Unlike the rejected strategy above, it doesn't rely on an independent conception of decency to explain why decent peoples are owed toleration. Decency is, rather, a concept that is internal to liberal political justification at international level.

My argument is structured as follows. In section 2 below, I take a closer look at the strategy of toleration in The Law of Peoples and distinguish in more detail the two objections that I claim are implicit in prominent critiques of that strategy. In section 3, I examine what I call 'international reasonableness': that characteristic which both liberal peoples and decent peoples share, in Rawls's view, and which marks them out as worthy of toleration in the sense that they are owed justifications in terms that they can accept for the Law of Peoples. In the following sections, I argue for my understanding of international reasonableness (and so decency) as an 'internal conception' that is not independent of the content of the Law of Peoples. I do this by arguing for an analogous understanding of (domestic) reasonableness in Rawls's theory of domestic justice, as advanced in Political Liberalism, in sections 4 and 5, and then explaining, in 
section 6, how the same approach underlies The Law of Peoples. I then reappraise The Law of Peoples, in section 7 , in light of this new understanding of international reasonableness. I conclude that Rawls's approach to international justice is both more coherent and more attractive than is often supposed.

\section{A closer look at Rawlsian toleration}

According to Rawls, a liberal people is a territorially bounded society that has a "reasonably just constitutional democratic government that serves [its members'] interests", "citizens united by what Mill called 'common sympathies", and "a moral nature" (Rawls 1999a: 23). ${ }^{4}$ A 'reasonably just' constitutional democratic government is understood here as one that accords with a reasonable liberal conception of justice such as Rawls's own 'justice as fairness'.

In Part I of The Law of Peoples, Rawls argues that the eight principles of the Law of Peoples are justified as principles for the regulation of the relations between different liberal peoples. The justification appeals to what I'll call the liberal peoples' original position (LPOP). This is a hypothetical choice situation which "models what we would regard... as fair conditions under which the parties [in that choice situation, who are] the rational representatives of liberal peoples, are to specify the Law of Peoples, guided by appropriate reasons" (Rawls 1999a: 32). 'We' who would regard the conditions in question as fair are members of well-ordered liberal societies, which means that we accept liberal domestic political principles (1999a: $32-3) .{ }^{5}$ As such, we would, according to Rawls, accept that the choice made by the parties in the LPOP should determine principles for the regulation of liberal peoples' relations. What they would choose is the Law of Peoples (1999a: 39-44). When the Law of Peoples regulates liberal peoples' relations, those liberal peoples are said to form the 'Society of Peoples' (1999a: 3). 
This argument complete, Rawls turns his attention in Part II to the question whether any non-liberal societies should be admitted to the Society of Peoples. Admission would entail a high degree of toleration of the new members' ways of organising themselves internally. Members of the Society of Peoples would be prohibited by the Law of Peoples itself from intervening by force in other non-liberal members' domestic affairs even if the latter implemented illiberal domestic policies, such as prohibiting homosexual acts or denying women the right to vote. ${ }^{6}$ Moreover, political and economic sanctions in response to such policies would also be restricted, as would official incentives intended to persuade members to alter them, so long as those members continue to abide by the Law of Peoples (Rawls 1999a: 59, 62, 84-5, 121-2). All members of the Society of Peoples, Rawls writes, are to be recognised as "equal participating members in good standing" (1999a: 59).

The ideal of public reason operative among members of the Society of Peoples means, however, that appropriate conduct towards other members is not only a matter of this kind of non-interventionist toleration. It also requires that the Law of Peoples be justifiable to each member in terms that each member accepts - that each member be included in the constituency of justification of the Law of Peoples. So, if non-liberal societies were to be admitted to the Society of Peoples, the Law of Peoples would have to be shown to be justifiable to them in this sense as well as to the liberal peoples who are the Society's original members. As Rawls says, the idea would not be "to prescribe principles of justice for them, but to assure ourselves that liberal principles of foreign policy are also reasonable from a decent nonliberal point of view" (1999a: $58)$.

According to Rawls, then, admission to the Society of Peoples entitles a member to toleration in two senses. It entitles the member to toleration in the sense that other members are not to intervene in its domestic affairs either by force or via official sanctions or incentives (that is: sanctions or incentives set up at the level of the Society of Peoples). And it entitles the member to toleration in the sense that the Law of Peoples is not only to be applied but also 
justified to that member. Henceforth, I'll reserve the term 'toleration' for the first of these senses alone-partly for clarity, but partly also because the second sense seems rather distant from an ordinary conception of toleration and thus only confusingly so labelled.

Should any non-liberal societies be admitted to the Society of Peoples? Rawls argues that some should indeed, ostensibly because it is a given that there are "other acceptable ways...of ordering society" besides liberal ones (1999a: 59). Societies that organise themselves in these other ways are worthy of the toleration and inclusion in the justificatory constituency that admittance to the Society of Peoples represents (1999a: 67). This suggests that Rawls has in mind some independent criterion that marks out certain non-liberal societies as worthy in this way, although this may be no more than an appeal to intuitive judgment. ${ }^{7}$ Not to admit such societies-for liberal peoples to govern their relations with such societies according to different norms, less tolerant of or less justifiable to them than those regulating the Society of Peopleswould count, for this reason, against the justice of the global institutional order.

Rawls's strategy, then, on what I'll call the standard reading, seems to comprise the following two steps. First, describe and justify on fully liberal grounds an institutional order to regulate relations between liberal peoples. Second, argue that such an order should be tolerant of and justified to societies independently identifiable as worthy of such toleration and justification.

As we've seen, the first step involves the LPOP, in which representatives of liberal peoples, equally situated behind a veil of ignorance that deprives them of knowledge which might inappropriately bias their choice, affirm the principles of the Law of Peoples. ${ }^{8}$

The second step, on this reading, comprises two sub-steps, which Rawls describes in Part II. In the first, Rawls outlines the criterion, which I'll call 'international reasonableness', which marks out certain societies as worthy of inclusion in the Society of Peoples. For a non-liberal society to be worthy of inclusion—-for it to be internationally reasonable-it must qualify as a people and it must be what he calls 'decent' (I'll say more about these below). Decent peoples, 
then, are internationally reasonable and so are to be admitted to the Society of Peoples. They are therefore owed the duty of justification that this implies. In the second sub-step, Rawls tries to discharge that duty by showing that the principles of the Law of Peoples would be acceptable to such societies. He does this by arguing that decent peoples would accept regulation by principles chosen in a second international original position in which representatives of decent peoples (and not liberal peoples) are themselves equally situated and deprived of knowledge of certain facts about their societies, and that the principles that would be chosen are those of the Law of Peoples. I'll call this second international original position the 'decent peoples' original position' (DPOP).$^{9}$

It turns out, then, that the liberal global order of the Law of Peoples is, fortuitously, acceptable not only to liberal peoples but also to decent peoples, who are, on this reading, independently identifiable as worthy of inclusion in the constituency of justification (or ‘justificatory inclusion’ for short). Rawls presents this as a kind of discovery (e.g. at 1999a: 60, 69). Critics suspect, however, that the Law of Peoples does not in fact represent a happy coincidence between the principles that liberal peoples would, in appropriate circumstances, choose for the regulation of their own interactions and the principles that non-liberal peoples who happen to be independently identifiable as worthy of justificatory inclusion would, in appropriate circumstances, choose for the regulation of their interactions. They think that representatives of liberal peoples in the LPOP would choose more demandingly liberal principles than Rawls says they would. ${ }^{10}$ They diagnose Rawls as watering down truly liberal global principles in order to pander to illiberal societies - as presenting, in effect, a modus vivendi as if it were a just peace. ${ }^{11}$ And they argue that it's incoherent for Rawls to do this, given his intolerance of illiberalism in his domestic theory of justice. ${ }^{12}$

There are two strands in this critique that it's important to distinguish. The first strand focuses on the choice of principles in the LPOP. The critics' concern here is with the first step in Rawls's argument as I outlined it above. They argue that the principles of the Law of Peoples 
aren't liberal enough, in the sense that they don't require those governed by them to be as liberal as the critics suppose they should be. ${ }^{13}$

The second strand focuses not on the choice of principles but on the idea that non-liberal peoples are worthy of the justificatory inclusion that's required by admission to the Society of Peoples. This, then, is a concern with the second step in Rawls's argument - in particular, with the second step's first sub-step. The critics argue that decent peoples, by virtue of the fact that they deny their members important liberal rights, show themselves to be unworthy of justificatory inclusion. $^{14}$

These two concerns are closely connected. Suppose that the principles of the Law of Peoples were as liberal in content as advocates of the first objection think they should berequiring, for example, that all members of the Society of Peoples be organised domestically according to liberal principles such as those of justice as fairness. (I'll say that in that case they would be 'fully content-liberal'.) In that case, internally illiberal peoples would be necessarily excluded from the Society of Peoples for as long as they remained illiberal. There could be no question of 'extending' the Law of Peoples to them. The question that Rawls discusses in the second step of his argument—-whether there are any non-liberal societies that should be admitted to the Society of Peoples, with the burden of justification to them that that implieswould be idle.

Although they are closely connected in this way, the two concerns should, on the standard reading, nevertheless be kept distinct. For they are independent of each other, and give rise to two distinct objections. You could object that the Law of Peoples is insufficiently contentliberal—perhaps you think its account of human rights is too minimal—and yet maintain that some non-liberal societies are worthy of justificatory inclusion. In that case, you might be an optimist, supposing that the more content-liberal account of human rights that you favour could in fact be shown to be acceptable to at least some illiberal societies. (To see this, imagine that the more content-liberal law of peoples that you envision is nevertheless not so liberal in content 
that only liberal societies could conform to it. That law of peoples might be acceptable to those non-liberal societies that could conform to it.) Or you might be a pessimist, supposing that there is a deep tension between international justice, requiring liberal human rights, and international legitimacy, requiring justifiability to both liberal and some non-liberal peoples.

Alternatively, you could at once object that Rawls is wrong to think that justificatory inclusion of some non-liberal peoples is necessary and accept that the principles of the Law of Peoples are sufficiently content-liberal. In that case, you would be in the position of those discussed by Rawls in $\$ 7.2$ of The Law of Peoples, who say that "there is no need for the Law of Peoples to develop....an idea of toleration...citizens in a liberal society should judge other societies by how closely their ideals and institutions express and realize a reasonable liberal political conception" (1999a: 60). In their dealings with non-liberal peoples, you might think, liberal peoples might adopt principles that are more or less content-liberal than those of the Law of Peoples, or they might stick with the latter; either way, there would be no need to justify their conduct to non-liberal peoples.

One possible objection, then, focuses on the content of the Law of Peoples; the other focuses on the justificatory constituency for the Law of Peoples. Neither Rawls's opponents nor his defenders distinguish these objections very clearly, principally (I believe) because all of the opponents argue that the parties in an appropriately constructed LPOP would choose fully content-liberal principles—requiring liberalism at the domestic level—for the law of peoples. The opponents recognise that for Rawls, justificatory inclusion is something that is due only to those admitted to the Society of Peoples. But as I said above, if the law of peoples were fully content-liberal, then illiberal societies would necessarily be excluded from the Society of Peoples, so the second objection appears moot.

In fact, however, if the standard reading of Rawls's argument that I just described is correct, then there is room to press the second objection independently of the first. This can be seen from the fact that the pessimistic view that I described a moment ago is not eliminated by the 
supposition that the parties in the LPOP would choose fully content-liberal principles. And, indeed, the second objection at some level clearly animates some of Rawls's critics. The charge of incoherence that is levelled at him by Caney, Pogge, and Tan, in particular, focuses not only on the contrast between his liberal domestic principles and his less liberal international principles, but also on the contrast between the respectful attitude that Rawls takes towards decent peoples at the global level and the dismissive attitude that he takes towards illiberal individuals at the domestic level (see e.g. Tan 2000: 29-30; Pogge 2001: 247 and 2006: 208; Caney 2002: 106-7).

Defenders of Rawls, meanwhile, typically argue that the parties in the LPOP have good reasons to endorse the less content-liberal principles of Rawls's Law of Peoples, and that this outcome isn't as implausible as the critics suppose (see e.g. Reidy 2004, especially section V; Freeman 2007a: 275-80). But even if that's true, the second objection stands.

It's this objection, the objection to Rawls's justificatory inclusion of decent peoples, that I want to focus on. Even though both critics and defenders of Rawls seem to accept the standard reading of Rawls's argument—in particular, the idea that the extension to decent peoples involves identifying those peoples as independently worthy of both toleration and justificatory inclusion - this objection has not received much attention in its own right. For example, David Reidy, a prominent defender of Rawls, more or less ignores the question, simply accepting Rawls's insistence that "the extent to which liberal democratic peoples may demand internal reform [of a non-liberal people] is a matter of international justice, the principles of which are to be arrived at...from a moral point of view common to all peoples" (Reidy 2004: 306-7). But the only reason he gives for endorsing this 'overlapping consensus' approach in the first place is that for liberal democracies to regard the class of those societies to whom justice is owed "as exhausted by liberal democratic bodies politic alone would be nothing short of manifest hypocrisy" (Reidy 2004: 298)—for liberal democracies were themselves once non-liberal, and nevertheless suppose that they were at that time the same people, owed justice in their relations with other peoples (Reidy 2004: 296-7). 
To be owed justice, however, is not to be owed justifications in terms that one accepts. Compare Rawls's domestic theory of justice. Unreasonable individuals are owed justice: their liberal rights are to be respected just as those of their reasonable co-citizens are (see Quong 2004). But they are not owed justifications in terms that they accept. Rawls's political liberalism, as I said above, makes no attempt to include adherents of unreasonable views in the overlapping consensus. If we follow both critics and defenders of Rawls in supposing that in Part II of The Law of Peoples Rawls identifies a criterion for justificatory inclusion that is independent of the argument that precedes it in Part I, then it is no answer to those who dispute that criterion to argue that it would be hypocritical of liberal peoples not to seek to justify their conduct to them. That simply begs the question. ${ }^{15}$

The second objection, then, has not been adequately dealt with. I'll argue, however, that it can be.

3. International reasonableness as a ground for toleration

For those who accept the second objection, the obvious culprit in Rawls's theory is the criterion of international reasonableness-in the case of non-liberal peoples, their decency. Since it is in virtue of a non-liberal people's decency that it is regarded as worthy of justificatory inclusion, and yet decency does not imply domestic liberalism, it makes sense to suppose that this criterion is the source of the supposed incoherence. Moreover, Rawls's reasons for taking decency to be a ground for toleration seem rather vague. ${ }^{16}$ He writes:

The reader has to judge whether a decent people, as given by [the criteria Rawls has outlined at Rawls (1999a: 64-7)], is to be tolerated and accepted as a member in good standing of the Society of Peoples. It is my conjecture that most reasonable citizens of a liberal society will 
find peoples who meet these two criteria acceptable... Not all reasonable persons will, certainly, yet most will. (Rawls 1999a: 67)

What exactly is the trait that I'm calling international reasonableness and that is shared by both liberal and decent peoples? The trait that they both share is that of being a (well-ordered) people. ${ }^{17}$ Peoples, to begin with, are a kind of group agent, composed of individuals participating in a single co-operative scheme. For a society to qualify as a people, it must be possible to view it as a co-operative scheme rather than what Rawls (2001: 6) calls "merely socially coordinated activity", such as a system of production in which the productive work is done by slaves (see Rawls 1999a: 65). A necessary condition of a society's being a co-operative scheme is that it secures the minimal human rights that are required by the Law of Peoples (Rawls 1999a: 68): the "special class of urgent rights" (Rawls 1999a: 75) including "the right to life (to the means of subsistence and security); to liberty (to freedom from slavery, serfdom, and forced occupation, and to a sufficient measure of liberty of conscience to ensure freedom of religion and thought); to property (personal property); and to formal equality as expressed by the rules of natural justice (that is, that similar cases be treated similarly)" (Rawls 1999a: 65). These human rights are given as a minimum in the organising idea of justice that underpins a people's legal system and is, in good faith, viewed as such by those who implement that system. (That idea of justice may be a liberal one, but it may alternatively be a "common good idea of justice" which specifies societal aims by reference to a comprehensive doctrine [Rawls 1999a: 65].) They express the idea that those members are co-operating moral agents, with both their own rational ends and a capacity to act from justice. Moreover, that idea of justice "allows an opportunity for different voices to be heard" via mechanisms for consultation and dissent (Rawls 1999a: 72). This is implicit in the idea that members are co-operating moral agents rather than merely coordinated rule-followers. As Reidy (2004: 297) explains, the result is that "both ruler and ruled are regarded and treated as human persons, even if not free and equal persons in a liberal 
democratic sense. Both share in some meaningful sense in the constitution of a political agency, the authority of which is, in turn, justified by reference to the good of all as real constitutive parts of that agency". ${ }^{18}$

Peoples are, in this sense, then, group agents. This is the first necessary condition of international reasonableness. The second is that they are moral agents. Rawls writes:

As reasonable citizens in domestic [liberal] society offer to cooperate on fair terms with other citizens, so (reasonable) liberal (or decent) peoples offer fair terms of cooperation to other peoples. A people will honor these terms when assured that other peoples will do so as well. $[\ldots]$ [Peoples] are not moved solely by their prudent or rational...interests, the socalled reasons of state. (1999a: 25-7)

As group moral agents, then, peoples have fundamental rational interests. These are expressed principally by their principles of (domestic) justice. A liberal people's rational interest is largely given by liberal principles of justice (Rawls 1999a: 32). A decent people's rational interest is largely given by its common good idea of justice (Rawls 1999a: 69). ${ }^{19}$ Conceiving of these as fundamental interests implies seeing political independence, security, and territorial integrity as fundamental also. But peoples are willing to moderate their pursuit of these interests in order to act from fair terms of co-operation with other peoples, provided those others do likewise. They have a moral nature. This is the second necessary condition of international reasonableness. ${ }^{20}$

These, then, are the conditions of international reasonableness, in virtue of which a society merits justificatory inclusion in the foreign policy of a liberal people. They are conditions that are met by both liberal and decent people (Rawls 1999a: 63). Rawls spends a great deal of time enumerating these conditions. Yet the reasons that he gives for supposing any society meeting them to be worthy of justificatory inclusion are, as I said, rather hazy. This gives proponents of the second objection an easy target. As I'll argue in the next few sections, however, Rawlsian 
liberalism contains the materials for a much more satisfying basis for justificatory inclusion, which neither Rawls nor his defenders bring out. This involves defending Rawls's conception of international reasonableness by appeal to a reading of what Rawls (1999a: 30-5, 67) explicitly claims is its domestic analogue: the reasonableness of individuals.

\section{Reasonableness in political liberalism}

Let's start, then, by considering the idea of reasonableness within Rawlsian political liberalism. Reasonableness enters the picture there as follows. A question for liberals of any stripe is: is liberalism consistent with its own realisation under favourable conditions (full compliance, a large population with good representation at all ages, a good stock of resources, etc.) (see Rawls 1993: xix)? If not, that's surely a serious flaw, to say the least. And you might worry that it's not, for the following reason. Under even the most favourable conditions, liberal institutions would engender diversity in reasonable conceptions of the good affirmed by citizens: this is "the normal result of the exercise of human reason within the framework of the free institutions of a constitutional democratic regime" (Rawls 1993: xviii). ${ }^{21}$ If such pluralism meant that large numbers of individuals would not be able to see the liberal principles regulating their society as justified, then the liberal institutions might tend to instability because support for them would be undermined (see Rawls 1993: xlii-xliii).

So, liberals must show that the reasonable pluralism that liberal institutions would engender would not tend to undermine the stability of those institutions. They can, according to Rawls, do this. For liberalism can be presented in a way that does not bring its justification into conflict with reasonable comprehensive doctrines, which permits adherents of those doctrines to affirm liberal political principles without prejudice to their other moral beliefs. How? Well, it can be presented as justified by appeal to certain fundamental ideas in such a way that there can be an 
'overlapping consensus' on the ideas and the justification. That overlapping consensus includes adherents of all reasonable comprehensive conceptions of the good (see Rawls 1993: xlvii, and Lecture IV).

Taking this question and the response seriously means taking stability seriously. More than that, it means taking seriously the idea that a person can be reasonable without being a comprehensive liberal. For suppose that you thought that no one could be reasonable without being a comprehensive liberal. In that case, you might worry about stability, but not what Rawls (1993: xxxix, 143) calls stability for the right reasons. For the right reasons would be guaranteed, as far as you were concerned, by a comprehensively liberal justification such as the one that Rawls offers in $A$ Theory of Justice. ${ }^{22}$ So long as a comprehensively justified liberalism was stable under the conditions of its own realisation, there would be no problem.

Now, the argument of $A$ Theory of Justice seems to show, at least to the likely satisfaction of an early-Rawlsian comprehensive liberal, that a comprehensively justified liberalism will be more or less stable under the conditions of its own realisation. Those raised under liberal institutions, members of a well-ordered society, will come to internalise liberal principles as part of their sense of justice (see Rawls 1999b: chapter VIII), and that sense of justice will be congruent with their own good (where the latter is understood—unproblematically for the comprehensive liberal—in terms of Rawls's 'Aristotelian Principle' and certain Kantian ideas about autonomy, among other things) (see Rawls 1999b: chapter IX).

The only difficulty arises if some people begin to worry that their allegiance to liberal institutions might be the product of state indoctrination (Rawls 1999b: 451). In response to this difficulty, Rawls (1999b: 451) says in A Theory of Justice that we can lay before them the full, comprehensively liberal justification for the institutions under which they were brought up. But, of course, if they don't accept that justification because they are not themselves comprehensive liberals, for example, then we'll fail to convince them that their sense of justice isn't the product of state indoctrination. All the same, however, we-who are, as we're supposing, comprehensive 
liberals—-shall know that it isn't; so, as long as these people aren't so numerous or so upset by what they see as indoctrination as to undermine the stability of liberal institutions, we needn't view our failure to convince them as a problem. (And surely they won't be that numerous-the kind of reflection in question is pretty abstract, and seems unlikely to occupy most people very much if at all.)

Rawls does, however, think that it's reasonable not to be a comprehensive liberal. He thinks that a person can reasonably reject comprehensive liberal views. More than that, he thinks that it's one of the basic ideas of liberalism itself that any given comprehensive doctrine, including liberal ones, can reasonably be rejected. In consequence, the concern with stability for the right reasons becomes problematic, since we can't simply assume that a comprehensively liberal justification gives us the right reasons any more. (It could reasonably be rejected.) This is a major step away from the comprehensive liberal approach I described in the foregoing paragraphs. Why should we accept it?

The answer, I think, involves implicit appeal to the following plausible liberal methodological principle:

LMP: If your comprehensive liberal moral view commits you to principles of justice which are such that those who comply with them under ideal conditions need not at the same time subscribe to the comprehensive liberal moral view in question, then you're committed to justifying the resultant liberal political order to such people in terms that they can accept. $^{23}$

The idea is that the fact, when it is a fact, that liberal principles of justice for social institutions are fully complied with by adherents of non-liberal views is sufficient to show that these people are in an important sense not at fault. This faultlessness entitles them to respect, politically speaking, as a matter of liberal principle. And liberal respect, politically speaking, essentially 
involves justification of the political order and its guiding principles of justice to people in terms that they can accept (see Waldron 1987). ${ }^{24}$ Clearly, the people in question in some sense accept—they comply with—those guiding principles. ${ }^{25}$ But liberalism demands more than this. It demands justification.

Notice that this explanation does not appeal to any independent ideas about the reasonableness of subscribing to non-liberal comprehensive doctrines. Liberal respect for nonliberal doctrines is not prescribed on the grounds that they are reasonable according to some conception of reasonableness that liberals privilege even above their liberalism. That way of thinking would give too much critical force to the joke about the liberal being someone who can't take his own side in an argument. More seriously, it would make what Jonathan Quong (2005) calls the 'asymmetry objection' a serious problem for liberals even before they begin. ${ }^{26}$ The asymmetry objection asks why the factors that make it reasonable to affirm non-liberal comprehensive doctrines don't make it equally reasonable to affirm non-liberal conceptions of justice. Without a satisfactory answer to this question, liberals can't justify their liberalism at a political level, let alone at a comprehensive moral one. If a genuinely independent (i.e. nongerrymandered) conception of reasonableness is the deepest foundation of liberalism, a satisfactory answer looks unlikely.

I'll say a bit more about the asymmetry objection later. For now, note that it's not immediately suggested by the explanation of liberal respect for non-liberal comprehensive doctrines that appeals to the methodological principle LMP. For that explanation does not employ a conception of reasonableness that is independent of and assumed prior to the argument for liberal principles themselves, and which acts as a result as a constraint on that argument. (I'll call a conception of reasonableness that is independent in this way an external conception of reasonableness.) Rather, the reasonableness of a comprehensive moral view is marked out, according to the LMP-based explanation of liberal respect for reasonable such 
views, by the fact that it is compatible with full compliance with liberal political principles. ${ }^{27}$ That makes it what we can call an internal conception. ${ }^{28}$

If we accept an external conception of reasonableness, then, justice as fairness's turning out to be rejectable by people whom we can independently identify on that conception as reasonable will be sufficient to show that it's not stable for the right reasons, even if it's stable simpliciter. On an internal conception of reasonableness, by contrast, the test of stability for the right reasons does not involve appeal to the beliefs of any constituency apart from the members of a wellordered liberal society—one, that is, in which everyone accepts, complies with, and knows everyone else accepts and complies with liberal principles (see Rawls 2001: 8-9).

It's worth pointing out that a person's compliance with, and so in the relevant sense her acceptance of, a given set of liberal principles of justice need not imply that she takes those principles to be the ideal principles of justice. The internal conception of reasonableness, in other words, doesn't preclude reasonable disagreement about the most appropriate principles of justice. For one can see the fact that some principle is generally complied with and applies to one as a non-instrumental moral reason to act in accordance with it (so that one's so acting would constitute compliance) without thereby supposing that this situation is better than a situation in which some other principle is generally complied with and applies to one (see Gaus 2011: 398-400). Supposing that these principles are not the best possible principles, then, does not preclude complying with them as opposed to merely conforming with them. Nevertheless, as I'll argue in the next section, a person's acceptance of the liberal principles of justice in question does restrict the range of principles that she could see as better justified than these.

5. Two objections to the internal conception of reasonableness 
On my reading, then, Rawls thinks that it's one of the basic ideas of liberalism itself that any given comprehensive doctrine can reasonably be rejected, because it might be rejected by members of a well-ordered liberal society. The LMP says that such people are nevertheless owed justification in terms that they can accept. As a result, a necessary condition of a sound liberal theory of justice is that it can be justified to all reasonable individuals, regardless of the diversity in their comprehensive moral views.

The conception of reasonableness that is being invoked here is, to repeat, an internal conception, for what makes a person reasonable is simply that she is a member of a well-ordered liberal society, and what makes a comprehensive doctrine reasonable is simply that it might be held by such a person. ${ }^{29}$ Now, it's tempting to be suspicious of my employment of this conception in the stability-for-the-right-reasons test, for the following two reasons. First, it seems that people could accept liberal political principles and institutions for all sorts of absurd reasons. If a person is reasonable if she accepts such principles and institutions, as the internal conception of reasonableness has it, and if all reasonable people in the well-ordered society are owed justifications in terms that they can accept, as the LMP has it, then Rawlsian political liberals may find themselves required to give justifications that are acceptable to people who accept liberal principles and institutions, but whose acceptance of the liberal principles is based (only) on absurd reasons. But surely political liberals' justifications of liberal principles don’t have to be compatible with such absurd reasons. I'll call this the 'absurd justifications' objection.

Second, if a person is reasonable if and only if she accepts liberal political principles and institutions, as the internal conception of reasonableness has it, then surely there's no value in showing that liberalism is stable for the right reasons under conditions of reasonable pluralism. For, since everyone accepts liberal principles and institutions, it will be by definition stable for the right reasons. Following Quong (2011: 147) again, I'll call this the 'spare wheel' objection, since if it's sound, the appeal to stability for the right reasons and the acceptability of liberal principles to reasonable people becomes trivial—a mere 'spare wheel'. ${ }^{30}$ 
I don't have space to discuss these objections in as much detail as they merit, but it's worth explaining briefly how the view I'm recommending would deal with them. Let's begin with the absurd justifications objection. It will help to have an example of an absurd reason for acceptance of liberal principles and institutions. Here is such a reason: "A little magic bird that sometimes speaks to me tells me to act in accordance with liberal principles and institutions, and I do what ever the magic bird tells me to do." Call someone who accepts this reason an ornitholator, and let her be representative of all those whose acceptance of liberal principles is based on similarly absurd reasons. According to the absurd justifications objection, it's not plausible to suppose that liberals' justifications for liberal principles must be acceptable to an ornitholator. But if an ornitholator would count as reasonable on the internal conception, then Rawlsian liberals who accept the internal conception are committed to justifying liberal principles to her in terms that she can accept. Therefore, the internal conception, and with it my reading of Rawlsian political liberalism, should be rejected.

The following options suggest themselves as possible replies to this objection:

1. Accept that we are committed to justifying a liberal political order to ornitholators in terms that they can accept, but insist that this is not absurd.

2. Deny that we are committed to justifying a liberal political order to ornitholators in terms that they can accept, because...

(a) ... ornitholators would not, as a matter of empirical fact, exist under the ideal conditions of a well-ordered society.

(b) ... ornitholators would not, as a matter of conceptual fact, exist under the ideal conditions of a well-ordered society.

(c) ... ornitholators are unworthy of our justificatory efforts in some independent sense. 
Option 1 is unattractive even if we concede that it is not absurd to be committed to justifying the political order to ornitholators. For if we're committed to justifying a liberal political order to the ornitholator in terms that she can accept, then the kinds of justification that we will have to offer to her cannot be justifications that anyone else could accept. So, the reasons that people have for seeing the political order as justified won't be shared reasons. ${ }^{31}$

Why should this matter? Well, the citizens of a stable society must be able, when it faces new circumstances and countenances new proposals, to discuss the merits and demerits of these, and then to rank them, by reference to its conception of justice. But if the only point of convergence in citizens' judgments about justice is the principles of justice themselves - and not, in particular, on any of the values that these express - then there may be no way to frame discussions and suggestions about ranking proposals one way rather than another except in terms that others (reasonably) reject. There may thus be no consensual way forward. Nor can this problem be resolved simply by putting everything to the vote, since democratic forms themselves are subject to the same problems. Convergence on liberal principles of justice alone, then, isn’t enough. Political liberalism's ‘public reason' must be, as Rawls (1999a: 144-7) puts it, 'complete'.

Option 2(a) would be a helpful answer if were clear what warranted the assumption that as a matter of empirical fact, everyone in the well-ordered society would accept the Rawlsian 'fundamental ideas' of society as a fair system of mutually advantageous cooperation, citizens as free and equal, and so on, from which a liberal political conception of justice might be constructed (see Rawls 1993: 3-46, especially sections 2-5). For in that case, we would have no need to ask ourselves what to say to the ornitholator: she simply wouldn't be present. But it is not clear what would warrant the assumption.

Let's turn, then, to option 2(b). 2(b), of course, entails 2(a), and so would also give us the explanation that we wanted for the empirical expectation. What could justify $2(a)$ ? The thought 
would have to be that it is conceptually impossible to internalise the principles of justice without at the same time accepting the fundamental ideas. So, once again, we would have no need to ask what might be said to the ornitholator: she wouldn't be present because she couldn't be a member of the well-ordered society.

But why not? Surely it would be possible to conform to the principles of justice without accepting the fundamental ideas. ${ }^{32}$ The thought has to be that it's not possible to internalise them—this being necessary for compliance as opposed to mere conformity—without accepting the fundamental ideas. One possible explanation for this might be that it's not possible to internalise a principle without a sense and acceptance of the values that underlie it. But then if the ornitholator sees (non-instrumental) value in conformity to the pronouncements of the magic bird (as, perhaps, a theist might see value in conformity to the pronouncements of God), there's no reason to suppose that her conformity to the principles of justice couldn't also be compliance.

It would be better if we could take option 2(c) and simply claim that the little bird justification of the ornitholator's acceptance of the principles of justice isn't a sufficiently good justification. But we'd want to do that in a way that was consistent with accepting that at least some theistic justifications of a theist's acceptance of the principles could be good justifications (for otherwise reasonableness would become much more restrictive than we were aiming to make it). Now, this wouldn't mean that we would have to grant that any theistic justification is a good justification for acceptance of the principles of justice. There could be something of justificatory value that only some theists' justifications for acceptance of the principles of justice have and that the ornitholator's justification lacks. But we can't just stipulate that what that is is the intermediary fundamental ideas. For if we do that, then the notion of a sufficiently good justification smuggles in, effectively, an external conception of reasonableness which entails acceptance of the fundamental ideas. And an external conception with a substantive component of that sort is both implausible and suspicious (for reasons that I explain below). 
So, what might feature in a theist's acceptance of the principles of justice as a result, ultimately, of her faith or belief in God, that would not feature in the ornitholator's acceptance of the principles of justice? I propose that any reasonable view must include (if only implicitly) a coherent story which connects its most fundamental commitments (e.g. to God's authority) to the principles of justice. If this is a necessary condition of the reasonableness of a comprehensive doctrine, then merely replacing the little bird with God, for example, will not make the doctrine any less unreasonable, since there would still be no story which connects God with the principles of justice. By contrast, a story about how much God—or, indeed, the little bird-loves humans might well allow the doctrine to meet the condition by connecting them in a coherent way—in a way that enables a person to understand, for example, why God's—or the little bird's—commands are to be obeyed. ${ }^{33}$

It's important to distinguish between a coherence condition of the sort I have in mindwhat we might think of as a requirement that views are reasonably held—and a necessary condition of reasonableness which specifies, by content, some view that it is unreasonable not to hold. Clearly the latter offers an unattractive option, for my purposes. It runs against the grain of the internal conception of reasonableness that I'm defending here. The point of the LMP approach is that what counts as reasonable is primarily defined by compliance with and so internalisation of liberal principles of justice. To specify in advance some conception of reasonableness that rules out the need to justify the principles even to some of those who comply with them under ideal conditions, because those people do not accept some specified principle or set of ideas (such as the fundamental ideas), is to endorse an external conception of reasonableness which looks, as I said above, both implausible and suspicious. It looks implausible because so long as we do not conceive of reasonableness as an internal conception—as defined in terms of the liberal account of justice rather than independently of it - then it seems unlikely that to be reasonable will turn out to require adherence to just one particular evaluative view. And it looks suspicious because if this external conception of reasonableness is used to ground the denial that liberals are 
required to justify a liberal political order to some (as per $2[\mathrm{c}]$ ), then it will be hard to avoid the appearance of gerrymandering. For it would seem too great a coincidence that the particular normative ideas acceptance of which is entailed by reasonableness, on this external and therefore supposedly independent conception, should be precisely such as to guarantee acceptance of the liberal political order. ${ }^{34}$

The view I propose, then, is that LMP-accepting liberals are not committed to justifying the political order in terms that they can accept to people whose views, though they do support compliance with the principles of justice, are not appropriately coherent. Someone meets the coherence condition when there is a story to tell—a story which she at least implicitly accepts, or would accept under appropriate conditions — that pulls together both the principles of justice and her fundamental commitments in a story that makes sense of their relations to each other. Note that this condition is stronger than the condition that a person's compliance with the principles of justice be comprehensible in light of her fundamental commitments. The ornitholator meets this weaker condition. But she does not, without a story of the sort that I'm describing, meet the stronger condition. Her compliance is comprehensible in light of her commitment to obedience to the little bird, but the view as a whole doesn't include sufficient resources for satisfying answers - even from the point of view of someone who accepts it — to non-sceptical questions that any adequate view should be able to give (why these principles? what is the point of obedience? what makes you think that the little bird is to be obeyed rather than ignored?).

This requirement that there must be a story that makes sense of the relations between a person's fundamental commitments and the principles of justice is not a requirement that reasonable comprehensive doctrines satisfy strict norms of rationality. A story can make sense of the relations between fundamental commitments and principles of justice even though elements in the story aren't clearly consistent. The Christian doctrine of the Trinity, as Martha Nussbaum points out, "asks the believing Christian to believe a contradiction” (Nussbaum 2011: 
26). So, those Christians whose endorsement of the principles of justice is founded ultimately on Christian commitments which include affirmation of the doctrine of the Trinity would not have a story to tell about the relations between their fundamental commitments which satisfied strict norms of rationality. But if we can nevertheless make sense of such Christians' endorsement of political principles in light of their fundamental commitments—as Nussbaum's own discussion of the doctrine of the Trinity (ibid.) suggests that we can-then they satisfy the coherence condition that I am proposing. ${ }^{35}$

The coherence condition is a necessary condition of reasonableness, since it excludes those who do not meet it from the scope of liberal justification. But it is not itself either an internal or an external conception of reasonableness. This is because conceptions of reasonableness for the purposes of political liberalism give us sufficient conditions for inclusion in the scope of liberal justification. The relevant type of coherence is, rather, akin to citizens' rationality or the capacity to co-operate. It is also like these in that it sets a minimal and uncontroversial bar to qualification for inclusion in the constituency of justification (membership of the well-ordered society) that does not threaten to undermine liberals' commitment to liberalism itself, as an external conception of Rawlsian reasonableness does (see section 4 above).

Option 2(c) gives us, then, grounds to deny that political liberals who accept the LMP are committed to justifying liberal political principles to people who comply with those principles for absurd reasons. Members of the justificatory constituency specified by the LMP—reasonable citizens - meet a coherence condition which ensures that their fundamental commitments and their acceptance of the principles of justice are related by intermediary ideas which provide the resources for the kinds of satisfying answers to non-sceptical questions that any adequate comprehensive doctrine should be able to give. This is option 2(c). In light of this, we have reason to affirm 2(b) and, therefore, 2(a) as well.

When I rejected Option 1 I did so on the grounds that it gives us an inadequate picture of political liberalism's public reason. Do options 2(a)-(c) fare any better in this respect? One 
might worry that they do not. The coherence condition doesn't appear to require any particular set of intermediary ideas and values as components in the story that links individuals' fundamental moral commitments and their adherence to principles of justice. So, we might expect a wide range of inconsistent ideas and reasons to be the grounds of individuals' acceptance of such principles. Thus, there would be no guarantee that there will be a set of shared reasons sufficient for public reason to be complete.

This conclusion would be too hasty. It's true that the coherence condition on its own doesn't tell us anything about the values that operate as intermediaries between a person's fundamental commitments and the principles of justice she accepts. However, it does license conclusions about the ideas and values that operate as intermediaries between a person's fundamental commitments and the specifically liberal principles of justice that regulate a well-ordered society. For those principles are evidently expressive of or derived from the fundamental ideas of fairness, individual freedom and equality, and of society as a system of co-operation, as Rawls says they are. (To affirm this is not to deny that there may be other principles which also express those ideas, or contend that Rawls's derivation is uncontroversial.) Moreover, it's hard to see how the principles could be expressive of or derived from ideas and values that differed, in any substantial way, from these. If I'm right about this, then the coherence condition, in the context of a well-ordered society, gives us reason to suppose that each person accepts the fundamental ideas. Individuals who accept and comply with the principles of justice will also accept, and see the principles as expressive of or based on, the fundamental ideas. Consequently, the overlapping consensus will include those ideas together with the principles of justice; so, the public political culture will include shared resources adequate for public reason to be complete. ${ }^{36}$

Lest all this should sound over-optimistic, it's worth emphasising that the aim here is to show that the stability for the right reasons of the well-ordered society is likely, not that it is guaranteed. Its being likely doesn't imply, of course, that there could never be a member of the well-ordered society who both met the coherence condition and yet did not accept the 
fundamental ideas. (As I said above, it's hard to see how the principles of justice could be expressive of or derived from ideas and values that differed substantially from those appealed to by Rawls, but I don't see either how this could be ruled out altogether.) The existence of such a person would threaten the completeness of public reason and so the stability for the right reasons of the well-ordered society. But acceptance of the remote possibility of such a person is much less worrying for a political liberal than acceptance of the idea that ornitholators might be members of the well-ordered society and included, therefore, in the constituency of justification. It is perhaps unfortunate that political liberalism, on my reading of it, can't be shown to be consistent with its own realisation under all conceivable circumstances, even if it can be shown to be likely. But if it were an implication of the LMP that ornitholators were owed justification of the political order, that would be far worse.

I reject, then, the absurd justifications objection. I shall be briefer in addressing the spare wheel objection. That objection, recall, runs as follows. If a person is reasonable if and only if she accepts liberal political principles and institutions, as the internal conception of reasonableness has it, then surely there's no value in showing that liberalism is stable for the right reasons under conditions of reasonable pluralism. For, since everyone accepts liberal principles and institutions, it will be by definition stable for the right reasons.

The spare wheel objection is mistaken. There is value in showing that liberalism can be stable for the right reasons under conditions of reasonable pluralism, and that's because the internal conception of reasonableness doesn't entail acceptance of any liberal justification. It entails only acceptance of and compliance with liberal political principles—-that is, liberal principles for the institutions of the basic structure. Acceptance of such liberal principles doesn't entail acceptance of comprehensive liberal justifications for these liberal principles. (That's precisely the point of the fact of reasonable pluralism.) So, the possibility of stability that's not for the right reasons - the possibility that individuals who accept and comply with liberal principles for institutions may nevertheless not be in a position to see them as justified—remains open. To 
foreclose it, it must be shown that a justification for these liberal principles can be given that is acceptable to people who endorse different comprehensive doctrines despite their acceptance of liberal principles for the basic structure. And that means showing that there can be an overlapping consensus that guarantees that each member of it sees the liberal principles as justified. This task is a substantial one which involves showing, first, that the liberal principles can be justified by appeal to the fundamental ideas (Rawls's argument for this, which goes via the original position, is an instance of what he [1993: 89] calls political constructivism) and, second, that acceptance of the fundamental ideas can legitimately be assumed. I tried to make some headway with this second task in the foregoing response to the absurd justifications objection. As should be clear enough from that alone, showing that liberal principles will be stable for the right reasons is not a simple matter of definition.

6. An internal conception of international reasonableness

Armed with the LMP-based understanding of the role of reasonableness in political liberalism, we can now articulate a parallel and more satisfying defence of Rawls's justificatory inclusion of internationally reasonable societies. This way, we can vindicate not only that inclusion but also Rawls's (1999a: 33) insistence that his approach in The Law of Peoples is analogous to his approach in Political Liberalism. The idea is to interpret international reasonableness not, as is standard, as a rather sketchily defended external conception, but rather as an internal conception.

Recall that at the domestic level, Rawls thinks that a person can reasonably reject comprehensive liberal views, and hence that stability for the right reasons can be secured only by justification in terms that people who do reasonably reject comprehensive liberalism can accept. The supposition that a comprehensive liberal can't simply assume the right reasons and concern 
herself only with the stability simpliciter of liberal institutions called for explanation. I argued above that the explanation lies in Rawls's adherence to the LMP.

The same principle, mutatis mutandis, can be appealed to in order to explain Rawls's justificatory inclusion of decent peoples. In the international context, it holds that if the principles of the law of peoples that is worked out by appeal only to liberal ideas (as I'll say: a liberally justified law of peoples) are such that those societies that comply with them, under ideal conditions, need not at the same time subscribe to the liberal ideas that were appealed to in their construction in the first place, then adherents of the liberal ideas are committed not only to governing their relations with such societies by these principles, but also to justifying them to such societies in terms that they can accept. Just as liberal domestic principles would engender a pluralism of comprehensive views even when everyone complied with those principles, so liberal international institutions, according to this argument, might engender (or at least be consistent with) a pluralism of domestic conceptions of justice even when every society complied with the principles regulating those international institutions. And if Rawls is right to suppose that a liberally justified law of peoples is not a fully content-liberal law of peoples, then that is precisely the situation that we, as adherents of those ideas, face. In light of the methodological principles, therefore, Rawls is committed to justifying the Law of Peoples to decent peoples, who are simply those non-liberal peoples who nevertheless comply with the principles of the Law of Peoples.

This is why it is necessary for Rawls to show that decent peoples would accept "the original position as fair among peoples, and would endorse the Law of Peoples adopted by their representatives [in the DPOP] as specifying fair terms of political cooperation with other peoples" (1999a: 69). The possibility was always open, of course, that the Law of Peoples would turn out not to engender or be consistent with the relevant sort of pluralism-in other words, that there would be no societies who could at once be non-liberal and yet comply with the principles of the Law of Peoples. (In that case, 'internationally reasonable' would have turned 
out to be coextensive with 'internally liberal'.) Rawls's discussion is intended to show, however, both that there could be such societies and that the Law of Peoples could be justified to them.

It's worth stressing that the societies whose acceptance of the Law of Peoples might or might not be compatible with domestic non-liberalism are to be conceived as peoples, with everything that that term implies (see section 3 above). Otherwise, you might be suspicious of the suggestion that a society can comply with the Law of Peoples. The first necessary condition of a society's counting as a people is that it is a scheme of social cooperation in Rawls's sense (i.e. as distinct from mere socially coordinated activity), so that the members of that society may be seen as acting collectively, and capable of accepting and acting from any principles that they might collectively adopt. It is because of this that if a society is a people, its compliance with the Law of Peoples may be viewed as more than merely the compliance of the de facto authority in that society with the Law of Peoples, for example.

It might be objected to my account that the fact of reasonable pluralism gets explained, in Rawls's domestic theory, as the inevitable consequence of the operation of human reason under free (i.e. liberal) institutions, in light of what Rawls calls the 'burdens of judgment' (Rawls 1993: 54-8). By contrast, we've been offered no analogous explanation of what you might call the fact of internationally reasonable pluralism - that is, the supposed fact that the institutions of the Law of Peoples, under favourable conditions, would engender or be consistent with pluralism in societies' domestic conceptions of justice (cf. Caney 2002: 105-6).

In response, let me make two points. First, it is important to see that on my reading of Rawls's domestic theory, the question why the realisation of comprehensive liberalism, even under ideal conditions, is consistent with the existence of reasonable people who aren't themselves comprehensive liberals is secondary to the question what to do about it. The LMP requires that liberal institutions be justified to such people regardless of whether or not we have a satisfying explanation of how they come endorse different comprehensive doctrines, such as the burdens-of-judgment explanation that Rawls indeed goes on to give. On an external 
conception of reasonableness, by contrast, it makes sense to ask for explanations of the reasonableness of non-liberal views before one bothers to think about justifying liberal institutions to people who hold such views. For there's no point justifying those institutions to them if it can't be shown that it's reasonable to be non-liberal. So, the priority of the two questions is reversed. ${ }^{37}$

As I read Rawls, he is not operating with an external conception of reasonableness, either domestically or internationally. Consequently, the lack of an analogous explanation of internationally reasonable pluralism does not pose a particular problem for Rawlsian justificatory inclusion at the international level. It needs only to be plausible to suppose that there might be such pluralism. I take Rawls's (1999a: 75-8) description of the decent people 'Kazanistan' to be an effort to show that there might.

It's not surprising, moreover, that little empirical explanation for the fact of internationally reasonable pluralism is available. For we have no experience of such pluralism. In order to explain the fact of (domestic) reasonable pluralism, Rawls can perhaps avail himself of the evidence that surrounds him, since we live in pluralistic times under more or less liberal institutions. But we do not live under the institutions of the Law of Peoples. Empirical explanations of the pluralism that such institutions might engender are correspondingly more difficult to identify. ${ }^{38}$ One might suspect that something like the burdens-of-judgment explanation applies to peoples as well as to individuals. If that doesn't seem plausible, then until a liberal law of peoples is implemented, we must content ourselves with the intuitive plausibility of assuming diversity in domestic conceptions of justice under such a global order. But on my reading of Rawls, this is not particularly problematic.

7. The Law of Peoples reappraised 
In section 2 above I noted that the objection to Rawls's justificatory inclusion of decent peoples seems to be moot if those critics who argue that a liberally justified law of peoples would require domestic liberalism are correct. For if that's true, there's no possibility that decent peoples could be members of the Society of Peoples, and so no question of a requirement of public reason that the terms of membership should be justifiable to them. As I argued, however, if the correct conception of international reasonableness is an external conception, as critics and defenders alike appear to have assumed, then in fact the objection to justificatory inclusion can be pressed regardless of the success of the objection to toleration. For an external conception of international reasonableness would imply that a morally adequate law of peoples should be justifiable to decent peoples regardless of what fully liberal justifications of it entail. As I pointed out, there is room for both optimism and pessimism about the compatibility of the liberal justifications and the justificatory inclusion required by an external conception of international reasonableness that includes decent peoples.

By way of defence against the objection to justificatory inclusion, I’ve argued that Rawls should be read as employing an internal conception of international reasonableness. But on such a conception, the success of the objections to toleration really would make the question of justificatory inclusion inapplicable. To see this, suppose that a liberally justified law of peoples would be fully content-liberal — that is, it would disallow any form of domestic organisation apart from liberalism. According to the international analogue of the LMP (see section 6 above), if the principles of that law are such that those societies that comply with them, under ideal conditions, need not at the same time subscribe to the liberal ideas that were appealed to in their construction in the first place, then adherents of the liberal ideas are committed not only to governing their relations with such societies by these principles, but also to justifying them to such societies in terms that they can accept. For such societies are internationally reasonable. But if a liberally justified law of peoples would disallow any form of domestic organisation apart from liberalism, then there is no possibility of internationally reasonable yet non-liberal peoples. So, 
liberals are not committed to showing the law of peoples could be accepted by them. And so there is no question of justificatory inclusion for non-liberal peoples.

It transpires, then, that my defence of Rawls against the objection to justificatory inclusion of decent peoples is self-undermining if the objection to toleration turns out to be successful. A full defence of The Law of Peoples along the lines I am recommending requires, therefore, a defence of the less than fully content-liberal Law of Peoples that Rawls endorses. I don't have the space to offer a full defence, but I will sketch the main lines of what is, to my mind, the most plausible one.

The defence must show, in particular, that the LPOP is the appropriate constructivist procedure for a just law of peoples, and that the representatives of liberal peoples in the LPOP would not choose principles requiring domestic liberalism. The key points here, for our purposes, concern the fact that the parties in the LPOP are representatives of liberal peoples rather than of individuals, and the limits to a liberal peoples' fundamental interest in securing liberal justice domestically. ${ }^{39}$ For it is in virtue of their representing peoples rather than individuals that the parties are not motivated simply to safeguard the interests of individuals as given, according to Rawls's writing on domestic justice, by the 'two moral powers' — which motivation, Rawls argues there, leads to the choice of fully liberal principles. ${ }^{40}$ And it is in virtue of limits to the fundamental interest of liberal peoples in securing liberal justice domestically that it is not a requirement of the Law of Peoples that peoples be organised domestically according to a liberal conception of justice.

The decision to make the parties representatives of peoples rather than of individuals reflects the priority that Rawls accords to what I'll call the basic problem of social justice. That problem is a problem that faces societies-forms of cooperative association to which there is no alternative for individuals: "some workable [cooperative] arrangement is a necessary condition of the good of all" (Rawls 1971: 103; cf. 1993: 275-8). ${ }^{41}$ The problem is to find principles appropriate to regulate this essential form of co-operative association. For Rawls, this is the 
most fundamental problem of justice, and the problem of international justice is to be seen through the prism of his solution to that more fundamental problem, which is given in $A$ Theory of Justice and Political Liberalism. This is why he conceives of the Law of Peoples as principles for the foreign policy of a liberal democratic regime (Rawls 1999a: 9-10, 55, 82-83).

The necessity of social cooperation as a condition of anyone's good at all is what makes the basic problem of social justice fundamental. But why, one might ask, isn't the Law of Peoples conceived as part of the same problem, as it should be according to cosmopolitan critics who argue for a 'global original position' in which each individual in the world is represented by a party in the original position? ${ }^{42}$ The familiar Rawlsian answer to this question is twofold. In the first place, there is no need for the appropriately regulated co-operative association that solves the basic problem to be an association that includes all individuals in the world. The problem can be solved-justice can be done-within a much smaller association. So, a world of numerous such associations is no worse, in principle, than a world of only one. ${ }^{43}$ In the second place, there may be reasons to think that it would be better. Following Kant, Rawls (1999a: 36) suggests that "a world government... would either be a global despotism or else would rule over a fragile empire torn by frequent civil strife as various regions and peoples tried to gain their political freedom and autonomy". If that's true, then our initial statement of the basic problem of social justice should not assume that it is a problem to be solved by principles for a basic structure for a single, global society, as the critics' favoured global original position would. ${ }^{44}$ Only if we are already there, then - if we already have a basic structure of the sort that Rawls has in mind as the proper realm of applicability for principles of social justice_-should we conceive of global and domestic justice as the same problem. But we are not already there: the global institutions that exist today are not those of the basic structure of a single society in Rawls's sense. ${ }^{45}$

The foregoing reasoning raises the following important objection. Even if a world of many societies can solve the basic problem of justice, that doesn't show that the basic problem of justice can be solved by principles that apply only within a single society, as those that Rawls 
describes in A Theory of Justice and Political Liberalism are supposed to. It may be that a world of many societies solves the problem only thanks to a combination of societal and global principles, as cosmopolitans might argue. ${ }^{46}$ The global principles, as an essential element in the solution to the basic problem, would in that case have priority over anything that the LPOP procedure might produce. But Rawls's approach appears illegitimately to rule out this possibility in advance.

The response to this objection that I propose on Rawls's behalf is as follows. ${ }^{47}$ It may be true that even a society-focused solution to the basic problem of justice must include, at a fundamental level, principles that are global in scope alongside the principles for societies. But these global principles need not be egalitarian. They may, for example, require only that interactions between individuals respect Lockean norms of individual self-ownership. The egalitarian element in Rawls's own solution arises from the fact that members of a single society co-operate in the distinctive way that constitutes participation in the practice of life together as a single society and makes them a group agent. ${ }^{48}$ This fact makes special distributive norms to govern their relations with one another applicable that are not applicable to the relations between members of different societies.

Now, as the objection points out, the LPOP is constrained, on this view, not to produce principles that are inconsistent with the global principles already applicable as part of the solution to the basic problem. But if the global principles are less demanding than cosmopolitans tend to suppose, then this constraint need not jeopardise Rawls's conclusions about the results of the LPOP. ${ }^{49}$

Suppose, then, that the appropriately regulated co-operative associations that solve the basic problem of social justice are several, and that any global principles that are also required represent a constraint on the outcome of the LPOP. There remains a question how, within those constraints, the associations should relate to each other as the group agents that they are. (Is anything more required of them than compliance with the global principles?) Hence the decision to make the parties in the LPOP representatives of liberal peoples rather than of 
individuals. That decision does not alone explain the less than fully liberal content of the Law of Peoples, however. For one might think that given Rawls's specification of the fundamental interests of liberal peoples in terms of their securing liberal justice domestically, the parties would agree to institutions designed to ensure precisely that — through intervention by other peoples if necessary. ${ }^{50}$

But this would be to underestimate the importance of peoples' interests in autonomy and the autonomous achievement of justice. Rawls (1999a: 34; see also p. 118) says that peoples "strive to protect their political independence", an interest which is connected to their further interest in "proper self-respect of themselves as a people, resting on their common awareness of their trials during their history and of their culture with its accomplishments". As Reidy (2004: 304) notes, domestic liberalism itself is viewed with pride by a liberal people as a historical achievement—rather as an individual who lives a good life according to a particular comprehensive doctrine that she comes to endorse might see this as her own achievement. In each case, it matters that the agent in question should have arrived at the relevant point without having been forced to arrive there by others. The value of the achievement of liberalism for a people and the value of the achievement of the good life for an individual are both subject to something like Dworkin's 'endorsement constraint', which makes a person's endorsement of a conception of the good according to which her life is going better a necessary condition of her life's really going better. ${ }^{51}$ A people's self-respect is seriously damaged if its liberal democratic political institutions cannot be viewed by its members as their own collective achievement.

If we accept that peoples are group agents, as Rawls does, then this should not seem particularly implausible, particularly to liberals. Note that liberal democracy is not a necessary condition (on Rawls's account) of group agency, so it makes sense for a liberal people to view its liberalism as its achievement - that is, as the achievement of an agent that existed prior to its becoming a liberal people. It is at least arguable, in light of these points, that the parties in the LPOP would not agree to a law of peoples that licensed or required external intervention in 
people's domestic affairs to guarantee liberal institutions, even though they know that they have a fundamental interest in those institutions. For such principles would be inconsistent with peoples' independence and self-respect. And, since they know that they represent liberal peoples, and we take it as a given that domestic liberalism can be stable for the right reasons, they have no reason to suppose that their liberal democratic institutions are under any particular threat from within.

This is not to grant that any external intervention would be inconsistent with peoples' independence and self-respect. Intervention to ensure that a people remains a people in the face of internal threats of dissolution is perfectly consistent with that independence and self-respect. This is why parties in the LPOP would endorse the minimal human rights, and the intervention that these license, that are a condition of social cooperation and so group agency. There is no question of these violating a people's self-respect, since if intervention is called for by the Law of Peoples then the likely alternative to such intervention is that there ceases to be a people around to have any self-respect in the first place. ${ }^{52}$

It's worth noting, finally, that even if the principles that would be chosen in the LPOP would be more demanding with respect to peoples' internal organisation than those of Rawls's Law of Peoples, that doesn't show that my defence of Rawlsian justificatory inclusion is selfundermining. For, so long as the interest in independence and self-respect has sufficient weight to prevent the parties going so far as to choose principles that require fully liberal domestic institutions, then the possibility of non-liberal peoples who accept and act from the law of peoples remains. It is this possibility that my defence of Rawlsian justificatory inclusion depends upon.

The foregoing argument, if it's successful, explains why a liberally justified law of peoples would not permit members of the Society of Peoples to force other members to remain domestically liberal. The same kinds of considerations can also explain why a liberally justified law of peoples would not sanction other, non-coercive forms of intervention that might 
represent serious threats to members' independence and self-respect. As Joseph Raz (1986: $377-8,420)$ argues, manipulation is objectionable for the same reasons that coercion is objectionable: it interferes with individuals' autonomy. I understand Rawls's objection to liberal peoples' or the Society of Peoples's officially offering non-liberal decent peoples incentives to become more liberal in their domestic organisation to be an objection to manipulation that based on the same reasons as the objection to coercive interference just described..$^{53}$

A further difficulty that must be dealt with is as follows. Rawls doesn't explicitly say that the Society of Peoples will operate according to a norm of official non-criticism of members' internal affairs, so long as they continue to comply with the law of peoples. But I think (for reasons that I explain below) that he would endorse such a norm, even while accepting that liberal peoples may, when not speaking as representatives of the Society, criticise decent peoples' non-liberalism. ${ }^{54}$ If the content of the law of peoples is liberally justified in the way that I have outlined, however, one might wonder why a norm of official non-criticism should obtain. The reasons which explain the reluctance of the parties in the LPOP to choose principles licensing coercive intervention in each others' affairs except in cases of human rights abuses are not also reasons to suppose that they would choose a principle prohibiting official criticism of peoples' domestic non-liberalism. So, what are the grounds for an official norm of non-criticism for the Society of Peoples?

The grounds for such a norm lie in the in the fact that the public reason of a well-ordered society of internationally reasonable peoples would rule out any principle sanctioning criticism. Even if such a principle were affirmed in the LPOP and so one element in a fully liberally justified law of peoples, it would be superseded by norms of public reason for the Society of Peoples that would disallow criticism based on reasons not shared by all internationally reasonable peoples. By hypothesis, not all internationally reasonable peoples would accept reasons based on the justice of domestic liberalism, since some of them would not accept that conception of domestic justice. 
It might be objected that on the internal conception of international reasonableness, all internationally reasonable peoples would by definition accept those reasons, since according to the LMP to be internationally reasonable is to comply with the principles of the liberally justified law of peoples, which, we are supposing, would include the norm of criticism. But this would be to misunderstand the LMP. To see this, consider the way in which the LMP applies to a liberal theory of domestic justice. Some comprehensive liberals (e.g. liberal perfectionists) might suppose it to be permissible for the government to criticise the non-liberal comprehensive views even of individuals who comply with the principles of liberal justice in their relations with others. Even though such people were doing nothing politically wrong, as we might put it, such liberals would take it to be permissible for state officials to criticise their moral views. But the LMPendorsing justificatory liberal denies this, precisely because such people are doing nothing politically wrong by liberal lights. For acting in a way that draws perfectionist liberal criticism but that is not, by such liberals' lights, unjust is acting in a way that is not politically wrong. Liberals therefore owe them justification of the principles of justice terms that they can accept. As we saw in section 5 above, uncontroversial necessary conditions of reasonableness give us strong reasons to suppose that there will be a shared set of intermediary political ideas and values which may be appealed to in public reasoning about policies and proposals in the well-ordered society (and which enable us to say that public reason in that society is complete). The norms of public reason will prohibit state criticism of reasonable comprehensive doctrines, since no justification can be given for such criticism in terms that appeal only to the political ideas and values that make public reason complete.

In this way the norms of public reason supersede any norms of criticism of illiberal but reasonable comprehensive doctrines that might otherwise appear justified to liberals. The LMP thus explains the existence at the domestic level of a norm of official non-criticism such doctrines. And we can proceed analogously at the international level in order to explain the existence of a norm of official non-criticism of the illiberal internal organisation of 
internationally reasonable peoples. Of course, it is open to justificatory liberals not to accept the LMP, or to liberals not to be justificatory liberals at all. But the former will be vulnerable, as I've argued, to the asymmetry objection. And my argument is not directed at the latter at all.

\section{Conclusion}

Two strands can be detected in standard critiques of Rawls's toleration of decent peoples. The first strand represents a concern with toleration in the sense of non-intervention. The second represents a concern with justificatory inclusion. The two strands have typically not been properly distinguished. This, I suggested, is partly because if objections based on the first concern succeed, then the second concern may appear to be moot. However, on standard readings of Rawls, it is not.

Defenders of Rawls have typically focused on the first concern. They argue that there are good reasons to suppose that the LPOP is an appropriate decision procedure for determining the principles of the law of peoples, and that representatives of liberal peoples in the LPOP would choose the principles that Rawls says they would. I accept these reasons. Even if that is so, however, the question remains why we should see non-liberal but decent peoples' acceptance of those principles as a necessary condition of the principles' moral adequacy, any more than we should see illiberal individuals' acceptance of the principles of justice as fairness as a necessary condition of those principles' moral adequacy. In both cases, we might think, seeking acceptance is pandering to unreason.

I've argued that the answer to this question lies in an understanding of the Rawlsian conception of international reasonableness (the trait that decent and liberal peoples share) as an internal conception, rather than as an external one, together with an appreciation of the liberal methodological principle (LMP) that I take to underpin Rawls's approach. International 
reasonableness is simply willingness, on condition of reciprocal willingness in others, to comply with the law of peoples. If it is possible to be internationally reasonable in this sense and yet not liberal, as it is if the parties in the LPOP would choose as Rawls says they would, then according to the LMP liberals are committed to showing that the Law of Peoples could be justified to nonliberal but decent peoples. It is for this reason that Rawls's Law of Peoples not only tolerates such peoples but also includes them in the constituency of justification.

This reading shows Rawls to be less vulnerable than his critics suppose, and it offers us an attractive alternative to these critics' favoured cosmopolitan approaches. Beyond this, it shows there to be a satisfying unity to Rawls's work—a unity that he himself insisted on-and makes sense of what has been a real puzzle about The Law of Peoples.

\section{$\underline{\text { Notes }}$}

A version of this article was presented at the Manchester Centre for Political Theory seminar in March 2010. I am grateful to those present for their comments. Special thanks to Véronique Munoz-Dardé and Jonathan Quong for extensive discussion, comments, and suggestions, and to an anonymous referee for Politics, Philosophy \& Economics.

${ }^{1}$ In what follows I distinguish between the 'Law of Peoples' and the 'law of peoples'. The former, capitalised phrase refers to specifically the eight principles that Rawls advocates. The latter refers to sets of principles governing the relations between peoples. So, for example, a critic of Rawls might argue that the Law of Peoples should not be the law of peoples.

${ }^{2}$ See for example Pogge (1994: 215-9) and Tan (1998: 285).

${ }^{3}$ Here I follow Joseph Raz in distinguishing between compliance, which involves appreciating and acting for reasons that one takes to apply to one (in this case, the fact that the liberal principles of justice in question apply to one), and conformity, which involves only doing as those reasons specify, without necessarily doing so for those reasons. I take compliance in this sense with (the reason provided by) a 
principle to imply acceptance of that principle's applicability in the circumstances. See Raz (1999: 178$80)$.

${ }^{4}$ Mill (1991: 427) describes the members of nations as united by "common sympathies, which do not exist between them and any others—which make them co-operate with each other more willingly than with other people, desire to be under the same government, and desire that it should be government by themselves or a portion of themselves, exclusively".

${ }^{5}$ Rawls (1993: 35) defines a well-ordered society as one in which citizens accept and comply with liberal political principles.

${ }^{6}$ This is because the fourth principle of the Law of Peoples specifies that "Peoples are to observe a duty of non-intervention" (Rawls 1999a: 37). Intervention is justified only in the case of violations of human rights, which, on Rawls's view, don't include all the rights that citizens have in a liberal regime (see Rawls 1999a: 78-80).

${ }^{7}$ See for example Rawls (1999a: 67), where Rawls's defence of the criterion seems to be that "most reasonable citizens of a liberal society" would judge societies meeting it worthy of toleration.

${ }^{8}$ Inappropriate bias in the LPOP is to be understood on analogy with inappropriate bias in the (domestic) original position. There, Rawls supposes that it would inappropriately bias the parties' choice of principles of justice if they were to know such facts as their gender, social background, or productive talents, in light of the arbitrariness of these facts from a moral point of view (see Rawls 1999b: 10-19). Such facts are therefore hidden behind the veil of ignorance. In the LPOP, analogous facts include the "size of [a liberal people's] territory...the population...the relative strength of the people" (Rawls 1999a: 32). The domestic original position also excludes knowledge of individuals' comprehensive conceptions of the good; Rawls (1999a: 34) says that since a liberal people has no comprehensive conception of the good, there is nothing analogous to exclude in the LPOP. (The same is not true in the case of decent peoples: see note 9 below.)

9 Since decent peoples, unlike liberal peoples, have 'common good ideas of justice' (Rawls 1999a: 71), and since Rawls gives no reason to suppose that all decent peoples have the same common good idea of justice, the DPOP's veil of ignorance presumably excludes knowledge of represented decent peoples' 
common good ideas of justice as the domestic original position excludes represented individuals' conceptions of the good.

${ }^{10}$ This is the central contention of Pogge (1994), for example.

${ }^{11}$ See for example Pogge (1994: 215-9); Tan (1998: 285 and 2000: 31-2). For the idea of a modus vivendi, see Rawls (1993: 147).

${ }^{12}$ See for example Tan (2000: 30-1); Caney (2002: 106-7). Rawls's domestic theory of justice regards individuals who adhere to illiberal comprehensive doctrines as unreasonable (see Rawls 1993: 58-62; for the definition of a comprehensive doctrine, see Rawls 1993: 13). There is no attempt to show that the principles of justice as fairness are justified to them in terms that are consistent with their comprehensive doctrines (see Lecture IV in Rawls 1993).

${ }^{13}$ For one prominent statement of this strand, see Caney (2005: 84).

${ }^{14}$ For one prominent statement of this strand, see Tan (2006: 85-9; cf. Tan 2000: 27-8).

15 To the extent that Samuel Freeman, another prominent defender of Rawls, discusses the second objection, he too seems not to give it its due. He writes (2007a: 276): "The apparent reason for [toleration of decent peoples] is that liberal peoples have nothing to fear from a people if the latter endorses the Law of Peoples...there is no reason for...liberal peoples to refuse to tolerate decent peoples and recognize them as equals". But although Freeman may be right that the parties in the LPOP may choose less than fully content-liberal principles that are tolerant of decent peoples, that doesn't show that they must include decent peoples in the justificatory constituency for those principles.

${ }^{16}$ Freeman too is tentative on the subject, as the passage I quoted in the preceding footnote shows: he says there that the "apparent" reason for Rawlsian toleration is that liberal peoples have nothing to fear from decent peoples (2007a: 276). The same circumspection is present in Freeman (2007b), where he writes that Rawls "seems" to think that it is unreasonable for a liberal society to sanction decent peoples (434).

${ }_{17}$ Rawls (1999a: 63) refers to liberal and decent peoples together as 'well-ordered peoples'. To say that a society is 'well-ordered' means that "it is a society in which everyone accepts, and knows that everyone else accepts, the very same principles of justice...its basic structure...is publicly known, or with good 
reason believed, to satisfy these principles...And...its citizens have a normally effective sense of justice and so they generally comply with society's basic institutions, which they regard as just" (Rawls 1993: 35). ${ }^{18}$ For a more detailed examination of this idea, see the rest of Reidy's (2004) discussion.

${ }^{19}$ I say 'largely' in each case because Rawls (1999a: 34-5) stresses that "a further interest is also significant: $[\ldots]$ a people's proper self-respect of themselves as a people, resting on their common awareness of their trials during their history and of their culture with its accomplishment. Altogether distinct from their selfconcern for their security and the safety of their territory, this interest shows itself in a people's insisting on receiving from other peoples a proper respect and recognition of their equality".

20 'Outlaw states' meet the first condition, but not the second. They are analogous to individuals in a liberal society who are rational but not reasonable. 'Burdened states' meet neither condition, and it is because they do not meet the first that they cannot meet the second. They are analogous to those who fall outside the 'range property' of moral personality in Rawls's domestic theory, such as the severely mentally disabled. See Rawls (1999a: 90). For helpful discussion see section III of Reidy (2004). For Rawls's discussion of the range property of moral personality, see section 77 of Rawls (1999b).

${ }^{21}$ I say more about reasonableness below.

${ }^{22}$ Rawls claims that the justification in $A$ Theory of Justice is comprehensively liberal at Rawls (1993: xviii, xlii). This is on grounds that the discussion of congruence in Part III appeals to aspects of Kantian and Aristotelian conceptions of the good for individuals. For helpful discussion, see Freeman (2003).

${ }^{23}$ Note that I do not say reasonably accept, for reasons that should become clear shortly.

${ }^{24}$ Waldron (1987: 128) claims that liberalism's essential idea is that "all aspects of the social should either be made acceptable or be capable of being made acceptable to every last individual". On the understanding of political liberalism that I endorse, this is true, but we must be careful to distinguish between terms that every last individual accepts, terms that every reasonable individual accepts, and terms that every comprehensive liberal accepts.

${ }^{25}$ I say more below about the sense of acceptance which is implied by compliance.

${ }^{26}$ As Quong notes, the asymmetry objection has been pressed by many authors. 
${ }^{27}$ To say that a comprehensive doctrine is compatible with liberal political principles is to say that those who adhere to it are willing comply with those principles on condition that others do too. This conditionality of compliance isn't derived from any independent idea of reasonableness— the idea is not that it can independently said to be going beyond reasonableness to be willing to comply even when others don't. Rather, it's an aspect of Rawls's understanding of the notion of justice itself as that virtue in acting from which we all restrain ourselves for the benefit of all. It's not acting justly, even if it is praiseworthy, to restrain oneself in the relevant way even when others will not. (For an argument to the contrary, see Cohen 2009: 333.)

${ }^{28}$ Cf. Quong's discussion of internal and external conceptions of political liberalism in chapter 5 of Quong (2011), where he defends a similar view.

${ }^{29}$ It might seem that Rawls clearly does not subscribe to an internal conception of reasonableness, since he explicitly cashes out that notion in terms of (a) willingness to propose and abide by fair terms of cooperation provided that others do so too and (b) acceptance of the burdens of judgment and their consequences for the use of public reason (1993: 48-58), which seem independent of liberal theory and principles. I think that in fact Rawls intends this characterisation as a kind of filling-out of the internal conception of reasonableness that I describe in the main text. I say a little about this near the end of section 6 below.

${ }^{30}$ In fact, Quong distinguishes two spare-wheel objections. This is the second.

31 This is a problem that, in my view, undermines Martha Nussbaum's recent defence of Rawlsian political liberalism (Nussbaum 2011). Nevertheless, the degree of coherence that I go on to suggest is required for inclusion in the justificatory constituency may be smaller than that suggested by Rawls's (1993: 59) characterisation of reasonable comprehensive doctrines. Indeed, as Nussbaum (2011: 31) notes, Rawls's (1993: 159-60) comments later on in Political Liberalism indicate that he may in fact be more relaxed about the coherence of reasonable comprehensive doctrines than that characterisation suggests. Still, he should not be so relaxed as to include the ornitholator in the justificatory constituency. I say more about this below.

${ }^{32}$ For the distinction between conformity and compliance, see note 3 above. 
${ }^{33}$ It would be neat if comprehensive doctrines, on Rawls's definition, necessarily involved the kind of coherence I have in mind here. But they don't: see Rawls (1993: 13).

${ }^{34}$ Such an external conception wouldn't be vulnerable, at least, to the asymmetry objection (see section 4 above) since it wouldn't prompt the question why it's unreasonable to differ on moral matters but not on political ones. However, any attempt to clarify, in order to avoid the concerns about gerrymandering and implausibility, it by appealing to some procedural or epistemic external conception (such as one based on the burdens of judgment) would, I think, prompt that question to the precisely the extent that it succeeded in allaying the concerns.

One way to escape this objection would be to interpret the conception of reasonableness in question as an internal conception, by claiming that a well-ordered society is one in which, by definition, each person accepts the fundamental ideas (on my view this is not part of the definition). This is the approach that Quong endorses. I don't accept this approach, but I don't have the space to address it adequately here. ${ }^{35}$ Nussbaum (2011), following Dreben (2003), seems to reject any kind of limits on the irrationality or incoherence of reasonable comprehensive doctrines. For the reasons that I mentioned at note 31 above, I think that this is too lenient. But Nussbaum is right to think that the conditions on reasonable comprehensive doctrines that Rawls (1993: 59) gives are too strict. My own view is that a reasonable interpretation of what Rawls says at this point shows him to be interested in something like my version of the coherence condition, even if he overstates what's required for the kind of coherence that he has in mind. He asks for "an intelligible view of the world" that covers "the major religious, philosophical, and moral aspects of human life in a more or less consistent and coherent manner" (1993: 59, emphasis added). Such intelligibility and more or less coherent and consistent coverage manifestly do not, however, require "singling out which values to count as especially significant and how to balance them when they conflict" (1993: 59), for example. My version of the coherence condition seems to me to capture what Rawls is interested in without overstating what's required.

${ }^{36}$ This is why I said, at the end of the preceding section, that acceptance of the liberal principles of justice that regulate a well-ordered society constrains the range of principles that a person could see as better 
justified than those. It confines it to those principles of justice that may be derived or expressive of the fundamental ideas.

${ }^{37}$ This is not to deny that if the only explanation of the persistence of non-liberal comprehensive doctrines under liberal institutions were individuals' irrationality, then there would be no need to justify the principles of justice to compliant non-liberals at all. It might be objected that if this is true, then it's not the case that the question what to do about pluralism is prior, as I claim it is, to the question why non-liberal comprehensive doctrines persist in a society regulated by liberal principles. But that individuals are rational is, like the coherence condition I described in section 5 above, among the ideal conditions which we assume when we ask about justification in the well-ordered society. Such ideal conditions guarantee that the question what to do about pluralism is worth asking - that justifications must be found that all members of the well-ordered society accept. They do not, however, give us an explanation of the persistence of non-liberal comprehensive doctrines in the well-ordered society. So, to assume the ideal conditions, and so to guarantee that the explanation of the persistence of non-liberal comprehensive doctrines is not the result of individuals' irrationality, is not tacitly to grant that the question about why those doctrines persist is prior to the question how to justify the principles of justice to those who adhere to them.

${ }^{38}$ Reidy (2004: 307-8) claims that the fact that many societies have not gone through the AmericanEuropean experience of religious fragmentation explains (at least in part) why they aren't domestically liberal. Should such societies be willing to endorse the Law of Peoples, as the relative weakness of that Law suggests that they might, this would be one element in a plausible empirical explanation of internationally reasonable pluralism.

${ }^{39}$ Rawls specifies that this is a large part of a liberal people's fundamental interest at Rawls (1999a: 33).

${ }^{40}$ The two moral powers are the power to have and pursue a (comprehensive) conception of the good, and the power to have and regulate one's conduct according to a sense of justice. See Rawls (1993: 18-9 and 1999b: 442). 
${ }^{41}$ I say that there is no alternative to the form of association, rather than to the association itself, in order to avoid objections stemming from the possibility that any given individual might join a different association.

${ }^{42}$ Such critics are numerous. See, for example, Pogge (1994); Beitz (1999 and 2000); Buchanan (2000); Tan (2000 and 2004); Caney (2002).

${ }^{43}$ This is perhaps dependent on the truth of Rawls's (1999a: 107-8) observations about the possibility of justice for resource-poor societies. Even if Rawls is wrong about that, however, the two components (domestic and international) in a Rawlsian approach are in principle capable of providing for justice for all, since that approach does not tell in principle against greater international resource distribution than Rawls endorses. On the possibility of additions to Rawls's view that take into account new empirical facts without changing his approach, see Freeman (2007c: 320-1).

${ }^{44}$ As I go on to note, Freeman (2007c: 305-8) stresses the absence of any existent global basic structure in Rawls's sense. This is in order to refute those critics who argue that since there is such a basic structure, Rawls's domestic theory, which is designed to produce principles applicable to the basic structure of society, should have global application. My point here is that there is also no reason to build into our statement of the basic problem of social justice that there ought to be a global basic structure in Rawls's sense.

${ }^{45}$ See Freeman $(2007 \mathrm{c})$ for a detailed argument to this effect.

${ }^{46}$ Such cosmopolitans would combine global fundamental principles of justice with the kind of practical non-cosmopolitan principles proposed by Goodin (1988).

${ }^{47}$ The view that I go on to describe here owes a lot to Miriam Ronzoni’s (2009) sophisticated approach, although I think that she underestimates the extent to which even the global principles must include norms of distribution.

${ }^{48}$ Note that it is not, on this view, merely the fact that the members of a society co-operate with each other that makes the special distributive norms applicable. It is the fact that they co-operate with each other in the distinctive way that constitutes life together in a society. Anti-cosmopolitans have argued convincingly that the mere fact of co-operation (as well as a range of other proposed grounds) alone 
cannot justify a restriction in the scope of Rawlsian egalitarianism to the relations of members of the same society (see e.g. Abizadeh 2007). But these arguments do not address the possibility that I am envisioning.

${ }^{49}$ See note 43 above. These issues are, of course, the focus on intense and ongoing debates, which deserve more attention than I can give them here. I hope to address them more fully at a later date. ${ }^{50}$ This point seems to go unacknowledged by Freeman (2007a: 275-6), who makes much of the parties' mutual disinterest and the consequence, as he sees it, that they will not have any interest in intervention in other parties' affairs.

${ }^{51}$ For the endorsement constraint, see Dworkin (2000: 268) and Kymlicka (2002: 216).

${ }^{52}$ Intervention to secure minimal human rights is somewhat analogous, therefore, to the provision in Rawls's domestic theory of some of the means (such as a minimal education, perhaps) necessary to secure the conditions for the exercise of individuals' first moral power. Without such means, a person may fail to be a person in the relevant sense: she cannot even form a conception of the good, let alone pursue it.

${ }^{53}$ For the objection to offering incentives, see Rawls (1999a: 84-5).

${ }^{54}$ Rawls explicitly admits such criticism (i.e. criticism of non-liberal peoples by liberal peoples who are not speaking as representatives of the Society of peoples) at Rawls (1999a: 84). Kok-Chor Tan argues that Rawls would accept a norm of official non-criticism of decent peoples' non-liberalism at Tan (2006: 81-3). My argument broadly follows his.

\section{$\underline{\text { References }}$}

Abizadeh A (2007) Cooperation, Pervasive Impact, and Coercion: On the Scope (not Site) of Distributive Justice. Philosophy \& Public Affairs 35(4): 318-358.

Beitz C (1999) Political Theory and International Relations. Princeton: Princeton University Press.

Beitz C (2000) Rawls's Law of Peoples. Ethics 110(4): 669-696.

Buchanan A (2000) Rawls's Law of Peoples: Rules for a Vanished Westphalian World. Ethics 110(4): 697-721.

Caney S (2002) Cosmopolitanism and the Law of Peoples. The Journal of Political Philosophy 10(1): $95-123$.

Caney S (2005) Justice Beyond Borders. Oxford: Oxford University Press. 
Cohen GA (2009) Rescuing Justice and Equality. Cambridge, MA: Harvard University Press.

Dreben B (2003) On Rawls and Political Liberalism. In: Freeman S (ed.) The Cambridge Companion to Rawls. Cambridge: Cambridge University Press, 316-346.

Dworkin R (2000) Sovereign Virtue. Cambridge, MA: Harvard University Press.

Freeman S (2003) Congruence and the Good of Justice. In: Freeman (ed.) The Cambridge Companion to Rawls. Cambridge: Cambridge University Press, 277-315.

Freeman S (2007a) The Law of Peoples, Social Cooperation, Human Rights, and Distributive Justice. In: Freeman S, Justice and the Social Contract. Oxford: Oxford University Press, 259-256.

Freeman S (2007b) Rawls. Abingdon: Routledge, 2007.

Freeman S (2007c) Distributive Justice and the Law of Peoples. In: Freeman S, Justice and the Social Contract. Oxford: Oxford University Press, pp. 297-321.

Gaus G (2011) The Order of Public Reason. Cambridge: Cambridge University Press.

Kymlicka W (2002) Contemporary Political Philosophy: An Introduction, 2nd edn. Oxford: Oxford University Press.

Mill JS (1991) Considerations on Representative Government. In: Gray J (ed.) On Liberty and Other Essays. Oxford: Oxford University Press, 203-467.

Nussbaum M (2011) Perfectionist Liberalism and Political Liberalism. Philosophy \& Public Affairs 39(1): 3-45.

Pogge T (1994) An Egalitarian Law of Peoples. Philosophy \& Public Affairs 23(3): 195-224.

Pogge T (2001). Rawls on International Justice. The Philosophical Quarterly 51(23): 246-253.

Pogge T (2006) Do Rawls's Two Theories of Justice Fit Together?. In: Martin R, Reidy DA (eds) Rawls's Law of Peoples. Oxford: Blackwell Publishing, 206-225.

Quong J (2004) The Rights of Unreasonable Citizens. The Journal of Political Philosophy 12(3): 314335.

Quong J (2005) Disagreement, asymmetry, and liberal legitimacy. Politics, Philosophy \& Economics 4(3): 301-330.

Quong J (2011) Liberalism without Perfection. Oxford: Oxford University Press.

Raz J (1986) The Morality of Freedom. Oxford: Clarendon Press.

Raz J (1999) Practical Reason and Norms, 2nd edn. Oxford: Oxford University Press.

Rawls J (1971) A Theory of Justice. Cambridge, MA: Harvard University Press.

Rawls J (1993) Political Liberalism. New York: Columbia University Press.

Rawls J (1999a) The Law of Peoples. Cambridge, MA: Harvard University Press.

Rawls J (1999b) A Theory of Justice, rev. edn. Cambridge, MA: Harvard University Press. 
Rawls J (2001) Justice as Fairness: A Restatement. Cambridge, MA: Harvard University Press.

Reidy DA (2004) Rawls on International Justice: A Defense. Political Theory 32(3): 291-319.

Ronzoni R (2009) The Global Order: A Case of Background Injustice? A Practice-Dependent Account. Philosopby \& Public Affairs 37(3): 230-256.

Tan KC (1998) Liberal Toleration in Rawls's Law of Peoples. Ethics 108(2): 276-295.

Tan KC (2000) Toleration, Diversity, and Global Justice. University Park, PA: Pennsylvania State University Press.

Tan KC (2004) Justice Without Borders. Cambridge: Cambridge University Press.

Tan KC (2006) The Problem of Decent Peoples. In: Martin R, Reidy DA (eds) Rawls's Law of Peoples. Oxford: Blackwell Publishing, 76-94.

Waldron J (1987) Theoretical Foundations of Liberalism. The Philosophical Quarterly 37(147): 127150.

About the author

Thomas Porter is Lecturer in Political Theory at the University of Manchester, UK. 